\section{Agroindustrial Science}

Website: http://revistas.unitru.edu.pe/index.php/agroindscience
Escuela de Ingeniería Agroindustrial

Universidad Nacional de Trujillo

\title{
Optimization of the functional properties of a drink based on tubers of purple mashua (Tropaeolum tuberosum Ruíz y Pavón)
}

\author{
Optimización de las propiedades funcionales de una bebida a base de tubérculos de mashua \\ (Tropaeolum tuberosum Ruíz y Pavón) morada
}

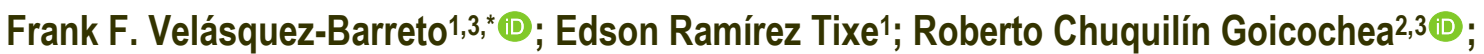 Isaac Aliaga-Barrera ${ }^{2,3}$}

\footnotetext{
${ }^{1}$ Escuela Profesional de Ingeniería Agroindustrial, Universidad Nacional Autónoma de Chota, Colpamatara, Chota, Peru

2 Escuela Profesional de Ingeniería Agroindustrial, Universidad Nacional de Huancavelica, Comun Era, Acobamba, Peru.

3 Proyecto FOCAM, Universidad Nacional de Huancavelica, Huancavelica, Peru.
}

\begin{abstract}
This work optimized the temperature and time of pasteurization of purple mashua (Tropaeolum tuberosum Ruíz and Pavón) tubers drink based on its antioxidant capacity, total phenolics, total flavonoids, anthocyanins content, and acceptability. For this, purple mashua tubers from the province of Acobamba-Huancavelica-Peru were weighed, washed, peeled, cut and placed in a juice extractor. The beverage of tubers was prepared using the juice of tubers, the thermal treatment of the samples was carried out at temperatures between 75 to $85^{\circ} \mathrm{C}$ and time 10 to $25 \mathrm{~min}$. The design was planned using a Rotational Composite Central Design and a response surface analysis was performed on the samples obtained. The content of total phenolics, anthocyanins, total flavonoids, and antioxidant capacity was influenced by the time and temperature of pasteurization. At higher temperatures and pasteurization times there was a reduction in the content of total phenolics, anthocyanins, total flavonoids, and antioxidant capacity. The greatest general acceptability of the panelists was at high pasteurization temperatures and times. The temperature of $77^{\circ} \mathrm{C}$ and time of 13 minutes showed the maximum value of response variables with low degradation of the antioxidant compounds and good acceptability of mashua extract drinks.
\end{abstract}

Keywords: Tropaeolum tuberosum; thermal treatment; antioxidant capacity; anthocyanins content; acceptability.

\section{RESUMEN}

Este trabajo optimizó la temperatura y el tiempo de pasteurización de los tubérculos de mashua (Tropaeolum tuberosum Ruíz y Pavón) morada en función de su capacidad antioxidante, fenólicos totales, flavonoides totales, contenido de antocianinas y aceptabilidad. Para esto, se pesaron, lavaron, pelaron, cortaron y colocaron en un extractor de jugo los tubérculos mashua morados de la provincia de Acobamba-Huancavelica-Perú. La bebida de los tubérculos se preparó usando el jugo de los tubérculos, el tratamiento térmico de las muestras se realizó a temperaturas entre 75 y $85^{\circ} \mathrm{C}$ y tiempo de 10 a 25 min. El diseño se planificó utilizando un diseño central compuesto rotacional y se realizó un análisis de superficie de respuesta en las muestras obtenidas. El contenido de fenoles totales, antocianinas, flavonoides totales y capacidad antioxidante fue influenciado por el tiempo y la temperatura de la pasteurización. A temperaturas más altas y tiempos de pasteurización hubo una reducción en el contenido de fenoles totales, antocianinas, flavonoides totales y capacidad antioxidante. La mayor aceptabilidad general de los panelistas fue a altas temperaturas y tiempos de pasteurización. La temperatura de $77^{\circ} \mathrm{C}$ y tiempo de 13 minutos mostraron un valor máximo de las variables de respuesta con baja degradación de los compuestos antioxidantes y buena aceptabilidad de las bebidas de extracto de mashua.

Palabras clave: Tropaeolum tuberosum; tratamiento térmico; capacidad antioxidante; contenido de antocianinas; aceptabilidad.

\section{Introduction}

Mashua (Tropaeolum tuberosum Ruíz and Pavón) also known as izañu, añu, or apiñu is an Andean tuber cultivated by people from the high Andean areas. It is one of the four main products of their diet, due to its hardiness, yield and nutraceutical potential (INIA, 2009). The mashua tuber is distributed in the Peruvian highlands, with its chemical composition containing $84.54 \%$ humidity, $0.98 \%$ protein, $0.13 \%$ fat, $0.51 \%$ ash, 
and $9.97 \%$ of carbohydrate expressed on the wet basis of the product (Velásquez-Barreto and Velezmoro, 2018).

Mashua purple tubers contain phenolic compounds such as gallic acid, procyanidins, hydroxybenzoic and hydrocyanic acid, rutin, myricetin, anthocyanins, epicatechin, proanthocyanidins, (Chirinos et al., 2007). Chirinos et al. (2008) also found a total content of phenolic compounds of $14-24 \mathrm{mg} / \mathrm{g}$ in dry matter of purple mashua variety DP 0224 and an antioxidant capacity (ORAC) in the range of $271-446 \mu \mathrm{mol}$ of Trolox equivalent $(\mathrm{TE}) / \mathrm{g}$ in the dry matter of purple mashua.

Research on natural antioxidants has increased knowledge about healthy components that are available in foods (Sardarodiyan and Sani, 2016). These antioxidants can have certain antiinflammatory, antitumor, antimutagenic, anticancer, antibacterial, and antiviral activities (Karker et al., 2016). These components can capture free radicals and final chain reactions before they can damage other molecules of vital importance (Singh et al., 2018). The effect of processing on the bioactive compounds present in food has been investigated, finding treatments such as blanching, pasteurization, sterilization, roasting, frying, refrigeration, freezing can reduce the content of bioactive compounds with antioxidant effect (Branco et al., 2016).

Industrial processing usually includes treatment at high temperatures like drying, sterilization, pasteurization, and roasting. These treatments are used to destroy pathogenic microorganisms and inactivate enzymes to increase the shelf life and availability of food for consumption (Branco et al., 2016). Pasteurization is a conservation method that is usually used due to its practicality and effectiveness. However, its use may involve the degradation of some compounds of interest such as vitamins, antioxidants, and amino acids (Brasili et al., 2017).

Degradation of bioactive compounds such as anthocyanins, total phenolics content, total flavonoids, and the antioxidant capacity of fruit juices and nectars by thermal treatment have been reported showing that the content of these compounds is altered by the intensity of the heat treatment (Brownmiller et al., 2008; Branco et al., 2016; Lu et al., 2018). Therefore, the evaluation of the thermal treatment variables such as temperature and time is of vital importance to reduce the degradation of the bioactive compounds.
Giving added value to some Andean tubers such as the purple mashua is of great importance for the Andean communities that cultivate this crop, and knowing the potential of this purple mashua tuber such as bioactive compounds and other components have been reported in some studies (Brizzolari et al., 2019; Apaza et al., 2020; Aguilar-Galvez et al., 2020). Therefore, this work had as objective: To optimize the temperature and time of pasteurization of purple mashua tubers drinks (Tropaeolum tuberosum Ruíz and Pavón) based on its antioxidant capacity, total phenolics, total flavonoids, anthocyanins content, and acceptability.

\section{Material and methods}

\section{Mashua tubers characterization}

The samples of purple mashua (purple variety) were collected from the province of AcobambaHuancavelica-Peru. The chemical composition of the tubers was determined using the methods of AOAC (2012). The content of total phenolics, antioxidant capacity, total flavonoid, and anthocyanin content of the mashua tubers were determined using the methodology proposed by Chirinos et al. (2008).

\section{Preparation of the sample}

Purple mashua tubers were weighed, washed, peeled, cut, and placed in a juice extractor (model FPSTJE318C-053, Oster, Peru) to extract the juice from the tubers. The extracts obtained were subsequently diluted in water in a $1 / 3$ ratio (extract/water); then the $\mathrm{pH}$ was adjusted to 3.5 . Sucrose was added until a Brix of 13 was obtained (this parameter was determined in the previous study). The design of the runs was performed using the Central Composite Rotational Design (DCCR). Thermal treatment of the samples was carried out at temperatures between 75 to $85^{\circ} \mathrm{C}$ and a time of 10 to $25 \mathrm{~min}$, with a total of 12 treatments. These factors levels were chosen due to the altitude of the zone and the parameters of pasteurization that normally are used. The response variables of mashua drinks analyzed before and after the heat treatment was total phenolic content, antioxidant capacity, total flavonoid content, monomeric anthocyanins content, and acceptability.

\section{Determination of antioxidant capacity}

The methodology proposed by Onyeoziri et al. (2016) with certain modifications were used. For this work, $10 \mathrm{~mL}$ of sample was diluted in $100 \mathrm{~mL}$ 
of distilled water. $1000 \mu \mathrm{L}$ of DPPH solution was added into a glass tube, followed by $50 \mu \mathrm{L}$ of diluted sample and $200 \mu \mathrm{L}$ of methanol. The final reaction volume was $1250 \mu \mathrm{L}$. The absorbances were measured in a spectrophotometer (Model 4251/50, Zuzi, Spain) at $515 \mathrm{~nm}$. Then, a calibration curve was prepared with $0.2 \mathrm{mM}$ of Trolox at concentrations of $0,20,40,60,80,100$, and $200 \mu \mathrm{M}$. The results were expressed in TEAC (Trolox Equivalent Antioxidant Capacity).

\section{Determination of total phenolic compounds}

The methodology proposed by Singh et al. (2016) with certain modifications was utilized to evaluate the total phenolic compounds. $125 \mu \mathrm{L}$ of the diluted sample $(1 / 10)$ was put in a glass tube and subsequently, $0.5 \mathrm{~mL}$ of deionized water and 125 $\mu \mathrm{L}$ of the Folin-Ciocalteu reagent were added., left to rest for $6 \mathrm{~min}$; then $1.25 \mathrm{~mL}$ of a $7 \% \mathrm{Na}_{2} \mathrm{CO}_{3}$ solution was incorporated and the total volume was adjusted to $3 \mathrm{~mL}$. This solution was incubated for 90 min and the absorbance was measured in a spectrophotometer (Model $4251 / 50$, Zuzi, Spain) at $760 \mathrm{~nm}$. The total phenol was expressed in gallic acid equivalent and a calibration curve of gallic acid was used from 20 to $500 \mu \mathrm{g} / \mathrm{mL}$.

\section{Determination of total flavonoid content}

The determination of total flavonoid content was performed using the methodology proposed by Singh et al. (2016) with certain modifications. $0.25 \mathrm{~mL}$ of the diluted sample (1/10) was used, and $75 \mu \mathrm{L}$ of a $5 \% \quad \mathrm{NaNO}_{2}$ solution was incorporated. Subsequently, $150 \mu \mathrm{L}$ of a fresh solution of $10 \% \mathrm{AlCl}_{3}$ was added, and $0.5 \mathrm{~mL}$ of a $1 \mathrm{M} \mathrm{NaOH}$ solution was incorporated. The final volume was adjusted with deionized water to 2.5 $\mathrm{mL}$ and incubated for $5 \mathrm{~min}$. The absorbance measurement was performed using a spectrophotometer (Model 4251/50, Zuzi, Spain) at 510 $\mathrm{nm}$. The catechin calibration curve was performed in the range of $10-500 \mu \mathrm{g} / \mathrm{mL}$. The total flavonoids was expressed as $(+)$ - catechin equivalent $[E C, m g(+)$ - catechin/g sample].

\section{Determination of monomeric anthocyanin content}

The methodology proposed by Machado et al. (2017) was used with certain modifications to determine the monomeric anthocyanin content of the samples. A dilution was prepared at $\mathrm{pH} 1.0$, $10 \mathrm{~mL}$ of the sample was diluted to $100 \mathrm{~mL}$ with buffer $\mathrm{pH} 1$ (0.025 M chloride buffer). Another dilution was prepared at $\mathrm{pH} 4.5,10 \mathrm{~mL}$ of the sample was taken and diluted to $100 \mathrm{~mL}$ with buffer $\mathrm{pH} 4.5$ (0.4 M sodium acetate buffer). Then, the absorbance for $\mathrm{pH} 1$ was determined in a spectrophotometer (Model 4251/50, Zuzi, Spain) at $510 \mathrm{~nm}$ and $700 \mathrm{~nm}$. The absorbance was also determined for $\mathrm{pH} 4.5$ at $510 \mathrm{~nm}$ and $700 \mathrm{~nm}$. The concentration of monomeric anthocyanins was determined using equations 1 and 2.

$$
\begin{gathered}
A b s=\left(A_{510 \mathrm{~nm}} p H 1.0-A_{700 \mathrm{~nm}} p H 1.0\right)- \\
\left(A_{510 \mathrm{~nm}} \text { pH } 4.5-A_{700 \mathrm{~nm}} p H 4.5\right) \ldots \ldots \text { (1) } \\
\text { Concentration }\left(\frac{\mathrm{mg}}{\mathrm{L}}\right)= \\
\frac{A}{\varepsilon L} \times 10^{3} \times \text { MW } x \text { Dilution factor....... (2) }
\end{gathered}
$$

Where: Abs: is the corrected absorbance, MW: Molecular weight (cyanidin 3-glucoside $=449.2 \mathrm{~g} / \mathrm{mol}$ ), $\varepsilon$ : Molar extinction coefficient (cyanidin 3-glucoside = $26900 \mathrm{~g} / \mathrm{mol})$, L: Length of the bucket $(1 \mathrm{~cm})$.

\section{Sensory evaluation}

The sensory evaluation of acceptability was carried out on the treatment runs. 60 untrained panelists were used to evaluate the samples. Samples were given to the panelists in the morning in random order. The rating was carried out with a hedonic scale of 7 points. Untrained Panelists were prepared to rinse their mouth with water after each sample evaluation.

\section{Statistical analysis}

Statistica 5.0 software was used to realize this analysis. The desirability function was used to determine the optimal parameters of pasteurization temperature and time. The optimal parameters of the factors and response variables were determined using the analysis of multiresponse of the Software Design Expert 7.0.

\section{Results and discussion}

\section{Physicochemical characteristics of purple mashua}

The percentages of moisture obtained (Table 1) are higher in the extracted juice than in whole mashua tubers because during the extraction process more liquid was extracted, separating the residue that is usually fiber. Chirinos et al. (2008) reported similar percentages of humidity in mashua tubers $(83.4 \%$ to $87.1 \%)$. The percentages of proteins, fats, carbohydrates, and ashes (Table 1) obtained in the present work are like those obtained by Velásquez-Barreto and Velezmoro (2018). Concerning the percentage of proteins, fats, carbohydrates, and ashes of the mashua extract, it was lower than those found in whole tubers of purple mashua because, during the extraction and filtration of the extracts, solid 
waste was left which reduced the content of these nutrients in the filtered extracts.

The content of anthocyanins, antioxidant capacity, total phenolics content, and total flavonoids of the mashua purple extracts were lower than the whole tubers of mashua purple because during the determination the whole tuber was used including the skin that increased the content of these components. The anthocyanin content of the purple mashua tubers (Table 1) was higher than those obtained by Chirinos et al. (2007) and Chirinos et al. (2008), where they found anthocyanin concentrations of 3.7 to 8.7 $\mathrm{mg} / 100 \mathrm{~g}$ and 11.4 to $13.6 \mathrm{mg} / \mathrm{g}$ respectively. The antioxidant capacity in purple mashua tubers (Table 1) was different from that obtained by Chirinos et al. (2007) who report antioxidant capacities in ORAC from 259 to $446 \mu \mathrm{M} / \mathrm{g}$. Moreover, Chirinos et al. (2008) obtained values of antioxidant capacity in ABTS from 165 to 601 $\mu \mathrm{mol}$ Trolox/g which are similar to those obtained in our work. Differences in the content of antioxidant capacity indicate that processes of synthesis and degradation of compounds with antioxidant properties occur and depend on the maturation and harvest process (Chirinos et al., 2007). The content of total phenolics of the purple mashua tubers was like those obtained from Chirinos et al. (2007) and Chirinos et al. (2008) who obtained values of 14 to $24 \mathrm{mg} / \mathrm{g}$ and 10.9 to $57.4 \mathrm{mg} / \mathrm{g}$ respectively. The content of total flavonoids was lower than those obtained by Chirinos et al. (2008) who obtained total flavonoid values between 1.8 to $7.8 \mathrm{mg} / \mathrm{g}$ in different varieties of mashua tubers. This indicates that genotypic differences could affect the total flavonoid content of the mashua tubers studied and other factors such as temperature, cultivation area, rainy season.

Table 1

Proximal chemical characteristics of purple mashua tubers

\begin{tabular}{|c|c|c|}
\hline Content & Whole tuber & Extract \\
\hline Humidity (\%)a & $86.87 \pm 0.36$ & $94.96 \pm 0.4$ \\
\hline Proteins (\%) a & $1.23 \pm 0.041$ & $0.51 \pm 0.01$ \\
\hline Fats $(\%)_{a}$ & $0.13 \pm 0.0031$ & $0.04 \pm 0.00$ \\
\hline Carbohydrates (\%)* & 11.41 & 4.34 \\
\hline $\operatorname{Ash}(\%)^{a}$ & $0.36 \pm 0.0073$ & $0.15 \pm 0.03$ \\
\hline Acidity $(\%)^{b}$ & $0.19 \pm 0.027$ & $0.21 \pm 0.03$ \\
\hline Brix & & $3.23 \pm 0.26$ \\
\hline Anthocyanins $(\mathrm{mg} / \mathrm{g})^{c}$ & $34.58 \pm 0.127$ & $26.69 \pm 0.0$ \\
\hline Antioxidant capacity $(\mu \mathrm{M} \text { trolox } / g)^{c}$ & $169.16 \pm 0.158$ & $142.35 \pm 0$. \\
\hline Total phenolics content $(\mathrm{mg} / \mathrm{g}) \mathrm{c}$ & $39.87 \pm 0.046$ & $37.57 \pm 0.0$ \\
\hline Total flavonoids $(\mathrm{mg} / \mathrm{g}) \mathrm{c}$ & $1.39 \pm 0.071$ & $1.27 \pm 0.03$ \\
\hline
\end{tabular}

*Determined by difference, ${ }^{\mathrm{a}}$ Expressed in wet weight, ${ }^{\mathrm{b}}$ Expressed in citric acid, cExpressed in dry basis.

\section{Total phenolic content}

The content of total phenolics was from 171.82 to $271.82 \mathrm{mg} / 100 \mathrm{~g}$ in the drinks of purple mashua extracts (Table 2). These differences are due to the different effects of the evaluated variables. The content of total phenolics was reduced at higher temperatures than $75{ }^{\circ} \mathrm{C}$ and pasteurization times greater than $13 \mathrm{~min}$. Besides, treatments performed at temperatures of $80^{\circ} \mathrm{C}$ and pasteurization times of 25 min showed the highest loss of total phenolics content. These data agree with those found by Klopotek et al. (2005), where the authors found a reduction in the content of total phenolics in juices and nectar from pasteurized strawberries at a temperature of $85^{\circ} \mathrm{C}$ and times of $5 \mathrm{~min}$. Likewise, Ma et al. (2013) found the reduction of polyphenols in carrot juices and grape juices due to pasteurization. Polyphenols present in mashua purple extracts suffered a thermal degradation that involves different reactions and perhaps was consumed in the Maillard reaction pathway (Ma et al., 2013). Besides, these results indicate that the pasteurization treatment may cause a degradation of polyphenols and the release of linked phenolic compounds.

\section{Antioxidant capacity}

The results of the antioxidant capacity measured by the DPPH method of the treatments of mashua extracts are presented in Table 2. The antioxidant capacity was 1442.61 to $1596.02 \mu \mathrm{M} / 100 \mathrm{~g}$, where it is shown that the antioxidant capacity was higher in treatments carried out at temperatures between 77 and $85{ }^{\circ} \mathrm{C}$ and pasteurization times less than $12 \mathrm{~min}$. However, pasteurization times greater than 12 min reduced the antioxidant capacity of the treatments. Brownmiller et al. (2008) found that the antioxidant capacity of clarified and pasteurized cranberry juices at temperatures of $95{ }^{\circ} \mathrm{C}$ for 3 minutes showed an increase from $1 \%$ to $7 \%$ in the initial antioxidant capacity of cranberry juices. Moreover, Hager et al. (2008) reported an increase of $24 \%$ and $25 \%$ antioxidant capacity in black raspberry juices pasteurized at $95^{\circ} \mathrm{C}$ for 3 min clarified and not clarified respectively. This supposes that the antioxidant capacity of the mashua extracts could have increased due to the high temperatures and short pasteurization times applied. Some studies have shown that the increase in antioxidant capacity during thermal treatment may be due to the formation of the products of the Maillard reaction (Zhang et al., 2018). On the other hand, by increasing the 
pasteurization times and the pasteurization temperatures, the antioxidant capacity of the mashua extracts was reduced, perhaps due to the loss of other antioxidants such as anthocyanins and polyphenols (Table 2). These results are related to the results obtained by Klopote et al. (2005) for juices and nectar of pasteurized strawberries, where the reduction of the content of anthocyanins and total phenolics content were related to the reduction of the antioxidant capacity.

\section{Total flavonoids}

The total flavonoid content of the drinks of purple mashua extracts is presented in Table 2. This content was 7.76 to $9.34 \mathrm{mg} / 100 \mathrm{~g}$. Pasteurization temperatures of 77 to $85{ }^{\circ} \mathrm{C}$ applied for times less than 15 min maintained the flavonoid content of the purple mashua extracts. Nevertheless, times greater than 15 minutes reduced the total flavonoid content. These differences in thermal treatments are perhaps due to prolonged times of heat treatment degrading the flavonoid content. Lu et al. (2018) reported the degradation of total flavonoids in orange juice because of the heat treatment temperature, this degradation was greater in high thermal treatment. Similar results were reported by Chaaban et al. (2017) who studied the thermal degradation of six flavonoids (rutin, naringin, mesquitol, eriodictyol, luteolin, and luteolin-7-0glucoside) at temperatures from 50 to $130^{\circ} \mathrm{C}$ and found that all flavonoids studied were sensitive to heat, and that sensitivity depended on the temperature and duration of thermal treatment. Likewise, they showed that the thermal stability of each flavonoid depended on its structure and treatment temperature. Similar effects of flavo- noid degradation were reported by Aoyama and Yamamoto (2007) on Welsh onions subjected to boiling. This would explain why temperatures of 77 to $85^{\circ} \mathrm{C}$ and pasteurization times greater than 15 min degrade the flavonoid content of mashua extracts in a greater proportion, and other factors such as $\mathrm{pH}$ could influence this behavior since low $\mathrm{pH}$ can degrade the structure of flavonoids at high temperature and a long time of pasteurization. It should be mentioned that the degradation of flavonoids depends on its structure. Buchner et al. (2006) observed that routine had greater stability compared to its aglycone (quercetin) and this is due to glycosylation in-ring $\mathrm{C}$. Besides, loannou et al. (2012) mention that the degradation of the flavonoids is not only a function of the temperature and time of thermal treatment but also of other parameters like $\mathrm{pH}$, presence of oxygen and other phytochemical compounds.

\section{Monomeric anthocyanin content}

The content of monomeric anthocyanins was from 230.70 to $350.18 \mathrm{mg} / \mathrm{L}$ (Table 2), where the anthocyanin content degradation was higher at temperatures of $77^{\circ} \mathrm{C}$ and pasteurization time of $13 \mathrm{~min}$. Although, it was lower at temperatures above $80{ }^{\circ} \mathrm{C}$ and times of $10 \mathrm{~min}$. The degradation of anthocyanins from various sources has studied such as blueberry (Song et al., 2018), purple corn (Kapcum and Uriyapongson, 2018), black carrot (Kirca et al., 2007), purple potatoes (Qiu et al., 2018), where it is reported that anthocyanin degradation is greater at high processing or storage temperatures and its degradation increases with longer treatment times.

Table 2

Results obtained from the purple mashua extracted treatments

\begin{tabular}{|c|c|c|c|c|c|c|c|}
\hline \multirow[b]{2}{*}{ Run } & \multicolumn{2}{|c|}{ Independent variables } & \multicolumn{5}{|c|}{ Responses Variables } \\
\hline & $\begin{array}{c}\text { Temperature } \\
\left({ }^{\circ} \mathrm{C}\right)\end{array}$ & $\begin{array}{l}\text { Time } \\
\text { (min) }\end{array}$ & $\begin{array}{c}\text { Total } \\
\text { phenolics } \\
\text { (mg/100g) }\end{array}$ & $\begin{array}{c}\text { Antioxidant } \\
\text { capacity } \\
(\mu \mathrm{M} / 100 \mathrm{~g})\end{array}$ & $\begin{array}{c}\text { Total } \\
\text { flavonoids } \\
\text { (mg/100g) }\end{array}$ & $\begin{array}{c}\text { Monomeric } \\
\text { anthocyanins } \\
(\mathrm{mg} / \mathrm{L})\end{array}$ & Acceptability \\
\hline 1 & 77 & 13 & 253.64 & 1596.02 & 9.06 & 319.37 & 3.6 \\
\hline 2 & 77 & 22 & 226.36 & 1522.16 & 8.11 & 280.29 & 4.1 \\
\hline 3 & 83 & 13 & 262.73 & 1561.93 & 9.17 & 335.17 & 4.9 \\
\hline 4 & 83 & 22 & 221.82 & 1505.11 & 8.71 & 268.27 & 5.2 \\
\hline 5 & 75 & 17.5 & 235.45 & 1465.34 & 9.34 & 298.33 & 4.2 \\
\hline 6 & 85 & 17.5 & 194.55 & 1516.48 & 9.32 & 247.98 & 5.5 \\
\hline 7 & 80 & 10 & 249.09 & 1578.98 & 9.14 & 315.61 & 4.8 \\
\hline 8 & 80 & 25 & 171.82 & 1567.61 & 7.76 & 230.70 & 5.3 \\
\hline 9 & 80 & 17.5 & 267.27 & 1488.06 & 8.88 & 346.42 & 5.1 \\
\hline 10 & 80 & 17.5 & 271.82 & 1442.61 & 8.59 & 341.16 & 5.3 \\
\hline 11 & 80 & 17.5 & 262.73 & 1448.3 & 8.71 & 350.18 & 5.1 \\
\hline 12 & 80 & 17.5 & 267.27 & 1465.34 & 8.76 & 348.67 & 5.2 \\
\hline
\end{tabular}


Also, Kirca et al. (2007) found that the greatest degradation of anthocyanins occurs at a $\mathrm{pH}$ greater than 3 and temperatures between 70 and $90{ }^{\circ} \mathrm{C}$. The degradation of anthocyanins maybe because of the breakage of the flavonols ion and as a result, it reduces the concentration of anthocyanins and loss of color. Buckow et al. (2010) mention that the thermal stability of anthocyanins is reduced by the number of hydroxyl groups in ring $A$, in the absence of dihydroxyl structures in ring $B$ and the degree of glycosylation in position 3 . Furthermore, Skrede et al. (2000) report that the stability of anthocyanins depends on the type of anthocyanins present. This behavior has been observed in delphinidin glycosides which showed a greater tendency to degradation at high temperatures due to their three ortho phenolic groups in the B ring in comparison with the derivatives of cyanidin that just have two ortho phenolic groups, which makes them more stable. On the other hand, the stability of anthocyanins at high temperatures is well known and is affected by long processing factors such as $\mathrm{pH}$, the presence of anthocyanin degrading enzymes, ascorbic acid, free radicals or oxygen (Kirca et al., 2007); which depend on the source of origin and processing conditions (Buckow et al., 2010).

\section{Sensorial evaluation}

Table 2 shows the acceptances of purple mashua drinks that are showing that at temperatures above $80{ }^{\circ} \mathrm{C}$ and times greater than $10 \mathrm{~min}$ increases the acceptability due to the thermal degradation of certain compounds that reduced the acceptability of the panelists. Likewise, during the sensory evaluation, the panelists stated that they found a slightly bitter and spicy taste in the samples that were pasteurized at low temperatures and short times. Some types of glucosinolates have been found in some varieties of mashua tubers (Martín and Higuera, 2016). Bitter flavors and smells have been found in the Brassicaceae family and these have been related to the presence of glucosinolates and their associated hydrolyzed products (Kim and Ishii, 2006). The presence of these glucosinolates could affect the acceptability of pasteurized purple mashua extracts that were pasteurized at lower temperatures and shorter times. Despite that, pasteurized extracts at higher temperatures $\left(>80^{\circ} \mathrm{C}\right.$ ) and longer times (>10 min) increased the acceptability and perhaps due to the degradation of the glucosinolates that were present before the pasteurization process. Barba et al. (2016) report that glucosinolates are susceptible to degradation at high temperatures which is dependent on the type of heat treatment applied. Furthermore, the authors mention that degradation is greater at boiling temperatures. This could explain why extracts treated at high pasteurization temperatures may have had a greater degradation of glucosinolates and, therefore, greater acceptability.

\section{Thermal treatment optimization}

Table 3 shows the regression coefficients of the quadratic models for the content of total phenolics content, antioxidant capacity, total flavonoid content, anthocyanin content and general acceptability of pasteurized purple mashua extracts.

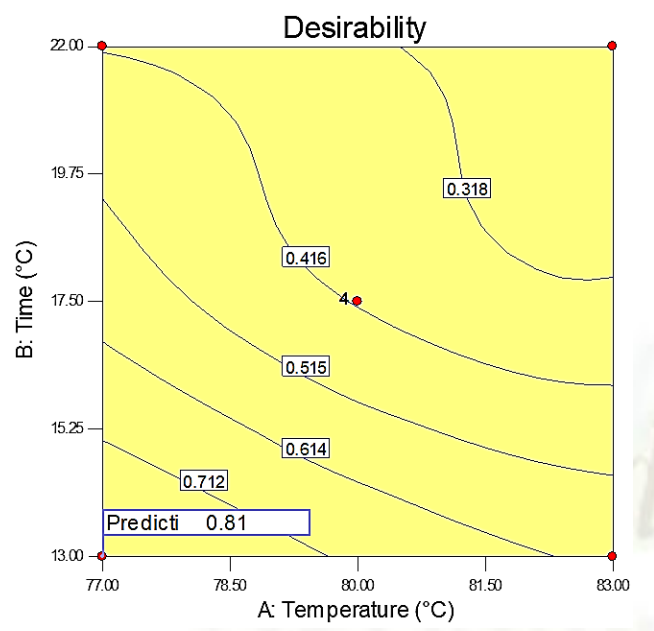

Figure 1. Desirability function for total response variables.

The quadratic models had a significant effect on the five studied variables $(p<0.05)$. Likewise, there was a lack of significant adjustment $(p<$ 0.05 ) in response variables content of total phenolics, anthocyanin content, and acceptability, which indicates that the proposed model was insufficiently accurate to predict these variables. High values of $R^{2}$ were observed in the content variables of total phenolics content, total flavonoid, and anthocyanin content $\left(R^{2}>0.9\right)$, except for antioxidant capacity (0.74) and acceptability (0.75). These results suggest that high variations of responses can be explained by response surface models. De Oliveira et al. (2009) report that the coefficient of determination greater than 0.8 and Loh et al. (2005) suggested that $R^{2}$ of 0.75 is adequate for prediction purposes. Also, the analysis of the residuals performed on the predicted data did not exceed $10 \%$ error, which indicates that the proposed quadratic models fit the experimental data very well. 
Table 3

Variance Analysis of the model for the response variables of purple mashua pasteurized extracts

\begin{tabular}{cccccc}
\hline Regression coefficients & Total phenolics & $\begin{array}{c}\text { Antioxidant } \\
\text { capacity }\end{array}$ & Total flavonoids & $\begin{array}{c}\text { Monomeric } \\
\text { anthocyanins }\end{array}$ & Acceptability \\
\hline$\beta_{0}$ & $-12570.8^{*}$ & 12578.52 & $165.7551^{*}$ & $-18744.7^{*}$ & $-137.958^{*}$ \\
$\beta_{1}$ & $313.6^{*}$ & -255.38 & $-3.7949^{*}$ & $463.9^{*}$ & $3.297^{*}$ \\
$\beta_{2}$ & $48.7^{*}$ & -104.39 & -0.6205 & $80.0^{*}$ & 0.509 \\
$\beta_{12}$ & -0.3 & 0.32 & 0.0091 & $-0.5^{*}$ & -0.004 \\
$\beta_{11}$ & $-1.9^{*}$ & $2.16^{*}$ & $0.0229^{*}$ & $-2.9^{*}$ & $-0.019^{*}$ \\
$\beta_{22}$ & $-0.9^{*}$ & -1.58 & -0.0055 & $-1.3^{*}$ & $-0.005^{*}$ \\
p value & 0.000 & 0.001 & 0.000 & 0.000 & 0.032 \\
p value of lack of fit & 0.0145 & 0.099900 & 0.243397 & 0.024775 & 0.008557 \\
$R^{2}$ & 0.9114 & 0.74 & 0.9409 & 0.95919 & 0.752 \\
$R^{2}$ ajusted & 0.83756 & 0.52864 & 0.89172 & 0.92517 & 0.54529 \\
\hline
\end{tabular}

Descriptors: $1=$ Temperature, $2=$ Time; *Significance at the level of 0.05 .

The desirability function (Figure 1) optimized the total phenolics content $(252.37 \mathrm{mg} / 100 \mathrm{~g})$, antioxidant capacity $(1559.16 \mu \mathrm{M} / 100 \mathrm{~g})$, total flavonoids $(9.28 \mathrm{mg} / 100 \mathrm{~g})$, the content of monomeric anthocyanins $(316.70 \mathrm{mg} / \mathrm{L})$, and acceptability (3.93) at $77{ }^{\circ} \mathrm{C}$ and $13 \mathrm{~min}$ of pasteurization with a maximum desirability value of 0.81 .

These parameters of temperature and time maximized the response variables and thereby permit to obtain drinks of extracts of purple mashua with good acceptability.

\section{Conclusions}

It was possible to obtain a functional drink with a high content of antioxidants. The content of total pheno-lics, anthocyanins, total flavonoids, and antioxidant capacity was influenced by the time and temperature of pasteurization. At higher temperatures and pasteurization times there was a reduction in the content of total phenolics, anthocyanins, total flavonoids, and antioxidant capacity. The greatest general acceptability of the panelists was at high temperatures and pasteurization times due to the degradation of compounds that provided a spicy and bitter taste probably related to the glucosinolate content of the drinks. The optimal temperatures and pasteurization times were $77^{\circ} \mathrm{C}$ and $13 \mathrm{~min}$. It is recommended to carry out an analysis of the compounds that produce abnormal flavors in the drinks of purple mashua extracts, as well as to evaluate the storage stability of the content of phenolics, anthocyanins, total flavonoids and antioxidant capacity of the obtained drinks.

\section{Acknowledgments}

To the National University of Huancavelica for financing the present investigation, with funds from the FOCAM projects.

\section{ORCID}

F. Velásquez-Barreto (DD https://orcid.org/0000-0001-8954-9769

R. Chuquilín (D) https://orcid.org/0000-0002-8751-691X

\section{References}

Aguilar-Galvez, A.; Pedreschi, R.; Carpentier, S.; Chirinos, R.; Garcia-Ríos, D.; Campos, D. 2019. Proteomic analysis of mashua (Tropaeolum tuberosum) tubers subjected to postharvest treatments. Food Chemistry 305: 1-9.

AOAC. 2012. Official Methods of Analysis of the Association of Official Analytical Chemists Methods: 925.09B, 920.39C, 960.52, and 985.29. Washington, DC., USA.

Aoyama, S.; Yamamoto, Y. 2007. Antioxidant activity and flavonoid content of welsh onion (Allium fistulosum) and the effect of thermal treatment. Food Science and. Technology Research 13(1): $67-72$.

Apaza, L.; Rumbero, A.; Orozco, O.; Ortega, M. 2020. Antimicrobial compounds isolated from Tropaeolum tuberosum. Natural Product Research (in press).

Barba, F.J.; Nikmaram, N.; Roohinejad, S.; Khelfa, A.; Zhu, Z.; Koubaa, M. 2016. Bioavailability of Glucosinolates and Their Breakdown Products: impact of Processing. Front Nutrition 3: $1-12$

Branco, I.G.; Moraes, I.C.; Argandoña, E.J.; Madrona, G.S.; Santos, C.; Ruiz, A.L.T.; Carvalho, J.E.; Haminiuk, C.W. 2016. Influence of pasteurization on antioxidant and in vitroantiproliferative effects of jambolan (Syzygium cumini (L.) Skeels) fruit pulp. Industrial Crops and Products 89: 225-230.

Brasili, E.; Chaves, D.F.S.; Xavier, A.A.O.; Mercadante, A.Z.; Hassimotto, N.M.A.; Lajolo, F.M. 2017. Effect of Pasteurization on Flavonoids and Carotenoids in Citrus sinensis (L.) Osbeck cv. 'Cara Cara' and 'Bahia' Juices. Journal of Agriculture and Food Chemistry 65(7): 1371-1377.

Brizzolari, A.; Brandolini, A.; Glorio-Paulet, P.; Hidalgo, A. 2019. Antioxidant capacity and heat damage of powder products from South American plants with functional properties. Italian Journal of Food Science 31: 731-748.

Brownmiller, C.; Howard, L.R.; Prior, R.L. 2008. Processing and Storage Effects on Monomeric Anthocyanins, Percent Pozlymeric Color, and Antioxidant Capacity of Processed Blueberry Products. Journal of Food Science 73(5): 77-79.

Buchner, N.; Krumbein, A.; Rhon, S.; Kroh, L.W. 2006. Effect of thermal processing on the flavonols rutin and quercetin. Rapid Communications in Mass Spectrometry 20: 3229-3235.

Buckow, R.; Kastell, A.; Terefe, N.S.; Versteeg, C. 2010. Pressure and temperature effects on degradation kinetics and storage stability of total anthocyanins in blueberry juice. Journal of Agriculture and Food Chemistry 58(18): 10076-10084.

Chaaban, H.; Ioannou. I.; Chebil, L.; Slimane, M.; Gérardin, C.; Paris, C.; Charbonnel, C.; Chekir, L.; Ghoul, M. 2017. Effect of heat processing on thermal stability and antioxidant activity of six flavonoids. Journal of Food Processing and Preservation 41(5): e13203. 
Chirinos, R.; Campos, D.; Arbizu, C.; Rogez, H.; Rees, J-F.; Larondelle, Y.; Noratto, G.; Cisneros-Zevallos, L. 2007. Effect of genotype, maturity stage and post-harvest storage on phenolic compounds, carotenoid content and antioxidant capacity, of Andean mashua tubers (Tropaeolum tuberosum Ruiz \& Pavón). Journal of the Science of Food and Agriculture 87: 437-446.

Chirinos, R.; Campos, D.; Warnier, M.; Pedreschi, R.; Rees, J-F.; Larondelle, Y. 2008. Antioxidant properties of mashua (Tropaeolum tuberosum) phenolic extracts against oxidative damage using biological in vitro assays. Food Chemistry 111: 98-105.

De Oliveira, M.A.; Maia, G.A.; De Figueiredo, R.W.; De Souza, A.C.R.; De Brito, E.S.; De Azeredo, H.M.C. 2009. Addition of cashew tree gum to maltodextrin-based carriers for spray drying of cashew apple juice. International Journal of Food Science \& Technology 44: 641-645.

Hager, A.; Howard, L.R.; Prior, R.L.; Brownmiller, C. 2008. Processing and storage effects on monomeric anthocyanins, percent polymeric color, and antioxidant capacity of processed black raspberry products. Journal of Food Science 73(6): 134140.

INIA. 2009. Instituto Nacional de Innovación Agraria. Accesiones promisorias; Banco de Germoplasma de la SUDIRGEB - INIA. Subdirección De Recursos Genéticos y Biotecnología-INIA, Perú

Ioannou, I.; Hafsa, I.; Hamdi, S.; Charbonnel, C.; Ghoul, M. 2012. Review of the effects of food processing and formulation on flavonol and anthocyanin behavior. Journal of Food Engineering 111: 208-217.

Kapcum, C.; Uriyapongson, J. 2018. Effects of storage conditions on phytochemical and stability of purple corn cob extract poder. Food Science and Technology (Campinas) 38(1): 301-305.

Karker, M.; Falleh, H.; Msaada, K.; Smaoui, A.; Abdelly, C.; Legault, J.; Ksouri, R. 2016. Antioxidant, anti-inflammatory and anticancer activities of the medicinal halophyte Reaumuria vermiculata. Excli Journal 15: 297-307.

Kim, S-J.; Ishii, G. 2006. Glucosinolate profiles in the seeds, leaves and roots of rocket salad (Eruca sativa Mill.) and anti-oxidative activities of intact plant powder and purified 4methoxyglucobrassicin. Soil Science and Plant Nutrition 52: 394-400

Kirca, A.; Ozkan, M.; Cemeroglu, B. 2007. Effects of temperature, solid content and $\mathrm{pH}$ on the stability of black carrot anthocyanins. Food Chemistry 101: 212-218.

Klopotek, Y.; K. Otto, K.; Bohm, V. 2005. Processing strawberries to different products alters contents of vitamin c, total phenolics, total anthocyanins, and antioxidant capacity. Journal of Agriculture and Food Chemistry 53: 5640-5646.

Loh, S.K.; Man, Y.B.C.; Tan, C.P.; Osman, A.; Hamid, N.S. 2005. Process optimisation of encapsulated pandan (Pandanus amaryllifolius) powder using spray-drying method. Journal of Science and Food Agriculture 85: 1999-2004.
Lu, Q.; Peng, Y.; Zhu, C.; Pan, S. 2018. Effect of thermal treatment on carotenoids, flavonoids and ascorbic acid in juice of orange cv. Cara Cara. Food Chemistry 265(1): 39-48

Ma, T.; Tian, C.; Luo, J.; Zhou, R.; Sun, X.; Ma, J. 2013. Influence of technical processing units on polyphenols and antioxidant capacity of carrot (Daucus carrot L.) juice. Food Chemistry 141: 1637-1644.

Machado, A.P.D.F.; Pereira, A.L.D.; Barbero, G. F.; Martínez, J. 2017. Recovery of anthocyanins from residues of Rubus fruticosus, Vaccinium myrtillus and Eugenia brasiliensis by ultrasound assisted extraction, pressurized liquid extraction and their combination. Food Chemistry 231: 1-10.

Martín, J.C.; Higuera, B.L. 2016. Glucosinolate composition of Colombian accessions of mashua (Tropaeolum tuberosum Ruíz \& Pavón), structural elucidation of the predominant glucosinolate and assessment of its antifungal activity. Journal of Science and Food Agriculture 96: 4702-4712.

Onyeoziri, U.P.; Romanus, E.N.; Onyekachukwu, U.I. 2016. Assessment of antioxidant capacities and phenolic contents of Nigerian cultivars of onions (Allium cepa I) and garlic (Allium sativum I). Pakistan Journal of Pharmaceutical Sciences 29(4): 1183-1188.

Qiu, G.; Wang, D.; Song, X.; Deng. Y.; Zhao, Y. 2018. Degradation kinetics and antioxidant capacity of anthocyanins in airimpingement jet dried purple potato slices. Food Research International 105: 121-128.

Sardarodiyan, M.; Sani, A.M. 2016. Natural antioxidants: sources, extraction and application in food systems. Nutrition \& Food Science 46(3): 363-373.

Singh, J.P.; Kaur, A.; Shevkani, K.; Singh, N. 2016. Composition, bioactive compounds and antioxidant activity of common Indian fruits and vegetables. Journal of Food Science and Technology 53(11): 4056-4066.

Singh, K.; Bhori, M.; Kasu, Y.A.; Bhat, G.; Marar, T. 2018. Antioxidants as precision weapons in war against cancer chemotherapy induced toxicity - Exploring the armoury of obscurity. Saudi Pharmaceutical Journal 26(2): 177-190.

Skrede, G.; Wrolstad, R.E.; Durst, R.W. 2000. Changes in anthocyanins and polyphenolics during juice processing of highbush blueberries (Vaccinium corymbosum L.). Journal of Food Science 65: 357-364.

Song, H-N.; Ji, S-A.; Park, H-R.; Kim, H-H.; Hogstrand, C. 2018. Impact of Various Factors on Color Stability of Fresh Blueberry Juice during Storage. Preventive Nutrition and Food Science 23(1): 46-51.

Velásquez-Barreto, F.F.; Velezmoro, C. 2018. Propiedades reológicas y viscoelásticas de almidones de tubérculos andinos. Scientia Agropecuaria 9(2): 189-197.

Zhang, Q. Wu, C.: Fan, G. Li, T. Wen, X. 2018. Characteristics and enhanced antioxidant activity of glycated Morchella esculenta protein isolate. Food Science and Technology (Campinas) 38(1): 126-133. 